\title{
Effect of wrack accumulation on salt marsh vegetation, Baruch Institute, Georgetown County, South Carolina
}

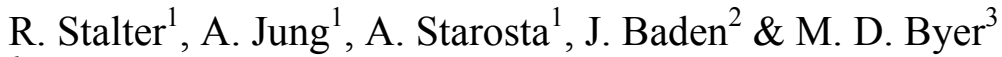 \\ ${ }^{I}$ Department of Biological Sciences, St John's University, Jamaica, \\ New York, USA \\ ${ }^{2}$ US Corps of Engineers, Wilmington, North Carolina, USA \\ ${ }^{3}$ Division of Natural Resources, Gateway National Recreation Area, \\ National Park Service, Staten Island, New York, USA
}

\begin{abstract}
In March 2004, four arrays in different types of salt marsh vegetation were covered with 15-20 cm of wrack secured in place, in an attempt to duplicate the natural deposition of wrack on the marsh by tides and storms, and to quantify and extend anecdotal observations and the results of previous studies. A control plot in each array was left uncovered; another plot was covered with only $2-3 \mathrm{~cm}$. The wrack was removed from one plot in each array at one, two, four and seven month intervals. One month of wrack coverage appeared to have little effect on either density or standing crop, recorded seven months after initial covering, of the principal marsh species. Above ground parts of these species, with the exception of Spartina patens and Borrichia frutescens, appeared to be killed or extremely inhibited after two months of wrack coverage or longer. Wrack 2-3 cm thick (never removed) appeared to have inhibited the marsh species after seven months, but not as much as the $15-20 \mathrm{~cm}$ wrack mat. These results are fairly consistent with those of an earlier study at Jamaica Bay Wildlife Refuge, New York City, that focused on responses to wrack of Spartina alterniflora only, except that two months' coverage seemed necessary to kill back most of the $S$. alterniflora in that study. However, in another study at Jamaica Bay encompassing several species and vegetation types, most species declined gradually with increased length of wrack coverage over a six-month period. Future studies will focus on recovery of the vegetation once the wrack has been removed, and on chemical changes in the soil caused by the decaying wrack, which may in turn affect the future course of vegetation development. Keywords: salt marsh, wrack, Baruch Institute, Georgetown, South Carolina.
\end{abstract}




\section{Introduction}

Salt marsh vegetation is typically dominated by a few grasses, rushes, and succulent dicotyledons $[1,5,6]$. A review of the literature dealing with salt marshes reveals that the same genera, e.g. Spartina, Distichlis, Juncus, and Salicornia are encountered in widely separated geographic regions.

One factor neglected in most salt marsh studies has been the impact of wrack deposition on salt marsh vegetation. Wrack is composed mostly of dead marsh plant stems and leaves. At the Baruch study site, it is made up primarily of Spartina alterniflora (salt marsh cordgrass). Wrack is naturally deposited upon salt marsh vegetation by tidal action. If wrack is thick enough and remains in place over the vegetation for a sufficient period of time, it will smother and kill the salt marsh plants with the exception of the woodier, more robust, or taller species such as, at Baruch, Iva frutescens ssp. oraria (high tide bush) and Borrichia frutescens (sea ox-eye). In an earlier study at Jamaica Bay Wildlife Refuge, New York City [3], Spartina alterniflora, at least its aerial parts, was killed in plots covered with wrack for 60 consecutive days or longer.

\subsection{The problem}

The objective of this present study was to investigate the effect of wrack coverage in several salt marsh sub-communities, described below under the heading "Site Description." Monitoring of the experimental manipulation of wrack mats may provide quantitative information useful in revealing: (1) the time needed for wrack to smother and kill major salt marsh species within previously undisturbed strands of several salt marsh vegetation types, (2) successional relationships as various salt marsh species invade areas uncovered after vegetation has been killed back by extended wrack coverage, (3) the time needed for each of the original species in each sub-community to reach parity with that species' importance before the artificial disturbance, (4) how long it takes wrack mats to decompose on site in each vegetation type.

\subsection{Site description}

The following sub-communities can be identified in the Baruch Institute salt marshes, along a gradient from lower to higher elevations:

1) The Lower Low Marsh sub-community is a near monoculture of Spartina alterniflora. A tall form of this grass up to $2 \mathrm{~m}$ occupies creek banks while a shorter form, generally less than $1 \mathrm{~m}$, is found on relatively higher ground. Environmental factors may be responsible for the different growth forms $[6,8]$. Our experimental array within this sub-community was located in a transition zone between the shorter form and the adjacent sub-community (no. 2, following).

2) The Upper Low Marsh sub-community is populated by a mixture of Salicornia sp. (salt wort, glass wort), Borrichia frutescens (sea ox-eye), Limonium carolinianum (sea lavender), Aster tenuifolius (salt marsh 
aster), and Spartina alterniflora. The abundance of each of these species within this zone is extremely variable.

3) In the Lower High Marsh sub-community, the dominant taxon is Sporobolus virginicus (seashore rush grass). Borrichia frutescens, Limonium carolinianum, Salicornia spp., and Fimbristylis castanea (marsh fimbry) also make up this sub-community.

4) The Upper High Marsh sub-community is dominated by a nearly pure stand of Spartina patens (salt meadow grass), occasionally associated with Borrichia frutescens, Iva frutescens ssp. oraria (high tide bush), and Distichlis spicata (spike grass).

\section{Methods}

Four arrays of permanent experimental plots were established in the subcommunities described above. Array 1, the lowest in elevation, was situated in the transition Low Marsh sub-communities, populated by a mixture of Spartina alterniflora, Salicornia spp., and Limonium carolinianum. The second array contained a mixture of Sporobolus virginicus, Salicornia, Borrichia, and Limonium. The third array was occupied primarily by Sporobolus virginicus. The fourth array's vegetation was a nearly pure stand of Spartina patens.

Each array was $1.5 \mathrm{~m}$ wide and consisted of seven $1 \mathrm{~m} \times 1.5 \mathrm{~m}$ plots in a row roughly parallel to the water's edge. In each of these plots, a central $0.5 \mathrm{~m} \mathrm{x} 1 \mathrm{~m}$ plot was marked off surrounded by a $0.25 \mathrm{~m}$ wide buffer zone $(0.5 \mathrm{~m}$ between adjacent plots). Each array was GPS-located and permanently marked at the corners, as were the $1 \mathrm{~m} \mathrm{x} 1.5 \mathrm{~m}$ and the $0.5 \mathrm{~m} \mathrm{x} 1 \mathrm{~m}$ plots.

In early March 2004, wrack was collected and placed upon each array at a thickness of 15-20 cm, except for one control plot, left uncovered, and one plot designated to duplicate the conditions used by Bertness and Ellison [2] in their experiments in a New England salt marsh. The latter plot, hereinafter called the "Bertness Plot," was covered with only 2-3 cm of wrack. To secure the wrack for the duration of the study, $6.5 \mathrm{~cm}$ mesh fish netting was laid over the arrays and held in place following the procedure described by Stalter et al [9].

In April, May, July, and October 2004, one plot in each array was uncovered. Wrack in the Bertness Plot in each array was left in place. During mid-October 2004, vegetation within each experimental plot and the control in each array was sampled using three randomly located $10 \mathrm{~cm}$ x $10 \mathrm{~cm}$ quadrats. Stems were first counted, by species. Then, the vegetation was cut at ground level, and used to determine standing crop $\left(\mathrm{gms} / \mathrm{m}^{2}\right)$. Data is presented in Tables 1 and 2 . Salt marsh species were classified according to Radford et al. [4].

\section{Results and discussion}

When the density (Table 1) of all species in all arrays is summed, there is a decline of 26 percent in numbers between the controls and the plots that were covered with wrack for one month. This difference could well be due, in whole or in part, to the small sample size. Total standing crop (Table 2) in the one- 
month plots is actually slightly greater than in the controls. In contrast to these moderate differences, there is a precipitous drop in both parameters between the one- and two-month plots; density and standing crop values for the latter are only 11 and 18 percent, respectively, of their one-month plot figures. Density and biomass are further reduced, less dramatically, in the four- and seven-month plots. From the two- through the seven-month plots, only one or two species were found in the four arrays combined.

Table 1: Density (no. $/ \mathrm{m}^{2}$ ) in October 2004, in four arrays, plots within the arrays covered with $15-20 \mathrm{~cm}$ of wrack for the intervals indicated in a salt marsh at Baruch Institute, South Carolina. Wrack was placed on the arrays in early March, 2004. Control plots were not covered; Bertness plots were covered with only $2-3 \mathrm{~cm}$, not removed.

\begin{tabular}{|c|c|c|c|c|c|c|c|}
\hline Array & Species & cntrl & $1 \mathrm{mo}$ & $2 \mathrm{mos}$ & $4 \mathrm{mos}$ & $7 \mathrm{mos}$ & Brtns \\
\hline \multirow[t]{3}{*}{1} & Spartina alterniflora & 1776 & 1686 & & & & \\
\hline & Salicornia spp. & 2708 & 967 & & & & 33 \\
\hline & Limonium carolinianum & m 173 & 25 & & & & \\
\hline \multirow[t]{4}{*}{2} & Sporobolus virginicus & 928 & 718 & & & & 67 \\
\hline & Borrichia frutescens & 8 & 47 & 80 & & & 133 \\
\hline & Limonium carolininum & 8 & 17 & & & & 28 \\
\hline & Salicornia spp. & 115 & 58 & & & & 67 \\
\hline \multirow[t]{3}{*}{3} & Sporobolus virginicus & 3658 & 3778 & & & & 94 \\
\hline & Limonium carolinianum & m 67 & & & & & \\
\hline & Borrichia frutescens & & & & & & 8 \\
\hline \multirow[t]{3}{*}{4} & Spartina patens & 1008 & 442 & 798 & 543 & 117 & 303 \\
\hline & Borrichia frutescens & & & & 25 & & \\
\hline & $\begin{array}{l}\text { TOTALS, ALL SPP. } \\
\text { IN ALL ARRAYS }\end{array}$ & 10449 & 7738 & 878 & 568 & 117 & 705 \\
\hline
\end{tabular}

The marked decline between one- and two-month wrack coverage is in marked contrast to results from a similar study carried out in a Jamaica Bay, New York City salt marsh, in which initial density and standing crop were both considerably greater, and declined gradually with increased duration of coverage through six months [9]. One possible explanation we can suggest is that with the warmer climate in South Carolina, there was greater microbial activity and faster wrack decomposition at the more southern site. Possibly, the heat and chemical bi-products thus generated caused a more rapid demise of the plants there. On the other hand, the different patterns seen in the two marshes might simply reflect the somewhat different plant sub-communities sampled, and differing sensitivities to wrack coverage of the species comprising them. 
Table 2: Dry weight $\left(\mathrm{gms} / \mathrm{m}^{2}\right)$, in October 2004 , in four arrays in a salt marsh at Baruch Institute, South Carolina. Details as in Table 1.

\begin{tabular}{|c|c|c|c|c|c|c|c|}
\hline Array & Species & cntrl & $1 \mathrm{mo}$ & $2 \mathrm{mos}$ & $4 \mathrm{mos}$ & $7 \mathrm{mos}$ & Brtns \\
\hline \multirow[t]{3}{*}{1} & Spartina alterniflora & 266 & 573 & & & & \\
\hline & Salicornia spp. & 219 & 373 & & & & 4 \\
\hline & Limonium carolinianum & n 23 & 4 & & & & \\
\hline \multirow[t]{4}{*}{2} & Sporobolus virginicus & 92 & 76 & & & & 5 \\
\hline & Borrichia frutescens & 11 & 37 & 65 & & & 282 \\
\hline & Limonium carolininum & 2.2 & 4 & & & & 5.7 \\
\hline & Salicornia spp. & 2.7 & 16 & & & & 52 \\
\hline \multirow[t]{3}{*}{3} & Sporobolus virginicus & 174 & 205 & & & & 34 \\
\hline & Limonium carolinianum & n 4.7 & & & & & \\
\hline & Borrichia frutescens & & & & & & 4.2 \\
\hline \multirow[t]{3}{*}{4} & Spartina patens & 783 & 609 & 280 & 202 & 100 & 254 \\
\hline & Borrichia frutescens & & & & 57 & & \\
\hline & $\begin{array}{l}\text { TOTALS, ALL SPP. } \\
\text { IN ALL ARRAYS }\end{array}$ & 1578 & 1897 & 345 & 259 & 100 & 641 \\
\hline
\end{tabular}

As to individual species, only Spartina patens, dominant in Array 4, and Borrichia frutescens, which occurs sporadically in small numbers in three of the arrays, appeared to withstand more than one month of wrack cover and were still resilient after four or seven months' coverage. In the case of Borrichia this is easy to understand, for this is a tall woody species whose leafy branches rise above the wrack. S. patens, on the other hand, may behave somewhat like Phragmites australis in the Jamaica Bay study [9]; both species send up awl-like shoots that can penetrate the wrack. S. patens did not show similar perseverance at Jamaica Bay [9]; it had declined to only 5 percent of its density in the control plot there after four months beneath the wrack, and had disappeared after six.

Spartina alterniflora, the grass that dominates the most area at both the Jamaica Bay and Baruch marshes, appears to be among the species most sensitive to wrack coverage. At Baruch, it was the only species that totally disappeared in the Bertness (2-3 cm wrack cover left in place) plots, and Byer et al. [3] found it to nearly or quite disappear after only two months' coverage at Jamaica Bay. However, Stalter et al. [9], in Jamaica Bay marsh, recorded good survival of $S$. alterniflora until four months of coverage and persistence in the Bertness plots. No possible explanation of this difference occurs to us. 


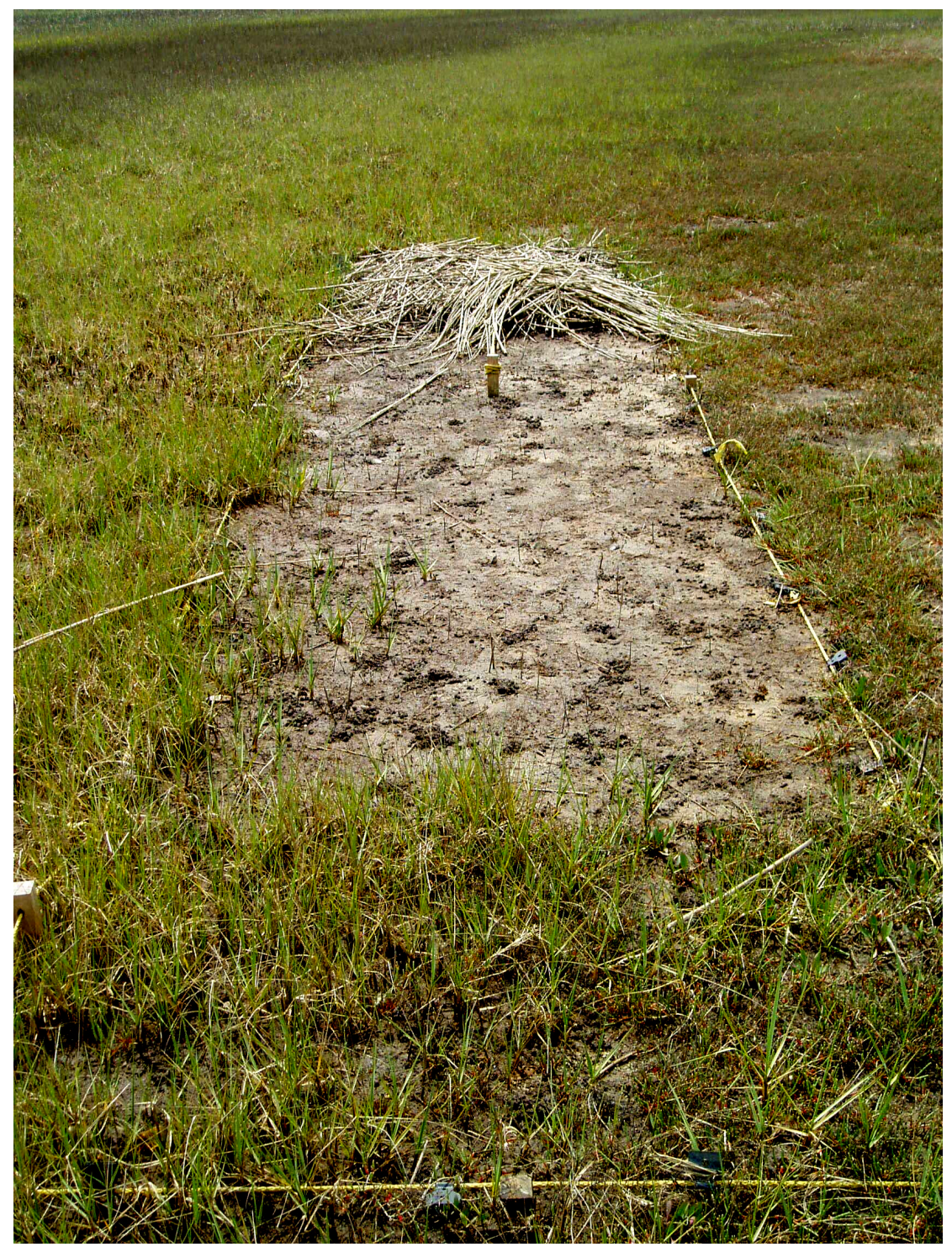

Figure 1: Array no. 1, October 2004. There is little difference in plant density in the control, below the horizontal rope in the above photo, and one month of wrack coverage, just above the rope. In contrast, the plots covered with wrack for two, four and seven months, extending from the one-month plot towards the pile of wrack in the background, are nearly devoid of vegetation. Photo by Paul Kenny.

One should bear in mind, in evaluating Tables 1 and 2, that the plots uncovered earlier had had more time to recover, by the time of sampling, than 
those uncovered later. We observed at the time of wrack removal, however, that after one month much of the vegetation was merely yellow or brown, whereas after two months or more, all vegetation had virtually disappeared except for $S$. patens and Borrichia. The vegetation that had been covered for one month recovered well in six months, whereas that covered for two consecutive months, with the exceptions noted, did not recover at all in five. Thus, the dramatic decline between the one- and two-month plots appears to be quite real.

In the Bertness plots, covered with only $2-3 \mathrm{~cm}$ of wrack left in place until sampling time, both density and standing crop of most species were somewhat to considerably less than in the controls, but greater than in plots covered with 15$20 \mathrm{~cm}$ for two months and more. This is consistent with results at Jamaica Bay [9]. Two to three cm of wrack, then, appears somewhat detrimental to growth and survival of salt marsh plants.

Bertness and Ellison themselves [2] found that in the Rhode Island marsh they studied, all plants of some of the same species involved in our study had been killed by $2-3 \mathrm{~cm}$ wrack after only 35 to 70 days. The methods used by these authors may provide the key to the much more rapid and total demise of all vegetation that they observed versus the persistence we recorded in similarly covered plots. Bertness and Ellison uncovered their plots briefly each week for monitoring purposes, then replaced the wrack and netting. This regimen likely caused much disturbance and mechanical damage to their plants, which possibly contributed to their quick destruction. We believe that our protocol of covering areas and removing the wrack only once, after varying intervals of time, provides a truer indication of the impact of the wrack itself.

What are the dynamics of an area in which the vegetation has been killed back by extended residence of wrack? It could become revegetated through (1) re-growth of the same species previously present from still-viable rhizomes or other subterranean parts, (2) vegetative re-invasion from the adjacent area, or (3) colonization by seed. Re-growth from existing subterranean parts was apparently the principal or only mechanism of recovery in those plots in which we recorded some plant material in October 2004. We will continue to observe recovery of these plots. Likely, vegetative re-invasion will play a role in those plots left completely bare on the aforementioned date. Seedlings, particularly those of Salicornia spp., typically colonize bare areas at Jamaica Bay. In the Baruch marsh, however, an extensive and systematic search for seedlings in the spring of 2005 revealed not a single one! Yet Stalter [6, 7] found that all South Carolina salt marsh species produced viable seed. The abundant fiddler crabs (Uca spp.) that populate this marsh may destroy seeds and seedlings, or else their constant movements disturb the substrate surface so severely that no seedling could survive.

We have found some Spartina alterniflora seedlings in areas denuded by wrack coverage at Jamaica Bay. George Frame (personal communication) found that numerous seedlings of this species colonized a new surface created by mechanical sediment deposition (a technique used to counteract rising sea levels) on a marsh at that location. Seedling recruitment may be an important recovery mechanism for vegetation at Jamaica Bay but, if the absence of seedlings at the 
Baruch marsh is typical of all years, then this marsh can only recover by vegetative means.

We plan to continue to monitor vegetation recovery following wrack residence at the Baruch marsh. Also deserving of investigation are possible chemical changes in the soil brought about by wrack decomposition, and how this affects the subsequent dynamics of the vegetation.

\section{Acknowledgements}

We are most grateful to Paul Kenny for his enthusiastic efforts removing additional wrack deposited naturally on our arrays by hurricane storm surges during the summer of 2004. We thank Dennis Allen, Director of the Baruch Institute for Marine Science and Ecological Research, for his support and cooperation. The staff of the Baruch Institute, especially Jan Blakely, was also helpful and supportive. Gratitude is due St. John's University, which provided funds to purchase supplies for this project, and to the Maintenance Division of St John's for preparing the stakes used in our wrack hold-down system. Doug Adamo, Chief of the Division of Natural Resources at Gateway National Recreation Area, is thanked for his authorization of travel to the Baruch Institute by the fifth author.

\section{References}

[1] Adams, D. A. 1963. Factors influencing vascular plant zonation in North Carolina salt marshes. Ecology 44(3): 445-456.

[2] Bertness, M., and A.M. Ellison. 1987. Determinants of pattern in a New England salt marsh plant community. Ecological Monographs 57: 129-147.

[3] Byer, M. D., G. W. Frame, W. Panagakos, M. Waaijer, Z. Aranbayev, Y. Michaels, R. Stalter and M. P. Schreibman. 2004. Effects of wrack accumulation on Spartina alterniflora, Jamaica Bay Wildlife Refuge, New York City. In: C. A. Brebbia, J. M. Saval Perez, and L. Garcia Andion (eds.). Coastal Environment V, Incorporating Oil Spill Studies, pp. 183-190.

[4] Radford, A. E., H. E. Ahles and C. R. Bell. 1971. Manual of the vascular flora of the Carolinas, University of North Carolina Press, Chapel Hill, North Carolina. 1183pp.

[5] Reidenbaugh, T. G., and W. C. Banta. 1980. Origins and effects of Spartina wrack in a Virginia salt marsh. Gulf Research Reports 6(4): 393-401.

[6] Stalter, R. 1968. An ecological study of a South Carolina salt marsh. Ph.D. dissertation. University of South Carolina, Columbia. 62 pp.

[7] Stalter, R. 1973. Viable seed production in five Atlantic Coast populations of Spartina alterniflora Loisel. Bulletin of the Association of Southeastern Biologists 20: 83-84. 
[8] Stalter, R., and W. T. Batson. 1969. Transplantation of salt marsh vegetation, Georgetown, South Carolina. Ecology 50: 1087-1089.

[9] Stalter R., A. Jung and M. D. Byer. 2005. Effect of wrack accumulation on salt marsh vegetation, Jamaica Bay Wildlife Refuge, New York City, New York. Ecosystems and Sustainable Development, V: 451-458. 